\title{
Penggunaan Material Limbah High Density Polyetylene (HDPE) Sebagai Bahan Pengganti Agregat Kasar Pada Campuran Beton
}

\author{
Arinda Rahmadiny ${ }^{1}$, Novadh Bargreitha ${ }^{1}$, Tommy Anggiawan Putra Pamungkas ${ }^{1}$, Ricky \\ Rialdi Chandra ${ }^{1}$, Mohamed Angky ${ }^{1}$, Agustinus Agus Setiawan ${ }^{2}$ \\ ${ }^{1}$ Program Studi Teknik Sipil, Universitas Pembangunan Jaya \\ ${ }^{2}$ Center for Urban Studies, Universitas Pembangunan Jaya \\ agustinus@upj.ac.id
}

\begin{abstract}
HDPE or High Density Polyethylene is one of the plastic material that is widely used for the manufacture of plastic packaging. Concrete is a composite building material made from a combination of aggregate and cement binders. The weight of the aggregate condition of the SSD obtained at 1.15 (requirement for fine aggregate is between 1 to 1.8) and has a degree of absorption against water by $3.945 \%$ (requirement max. $3.5 \%$ ), dry content weight $1378 \mathrm{~kg} / \mathrm{m}^{3}$ (maximum requirement max $1800 \mathrm{~kg} / \mathrm{m}^{3}$ ) and wear resistance (abrasion) artificial aggregate of $29.64 \%$ (maximum aggregate requirement used for concrete is 40\%). HDPE is a type of plastic that is white clean milk/white. Used for tissue bags, detergent bottles, oil, anti-heat plastics, plastic pipes, shopping bags and plastic bags that are normal for food vegetable. The largest concrete compressive strength is obtained at a temperature of up to $90{ }^{\circ} \mathrm{C}$ which is $13.16 \mathrm{MPa}$. When concrete mixed with 20\% HDPE waste produces concrete compressive strength of 11.08 $M P a$. However, the concrete mixed with the waste made by HDPE knot produces concrete compressive strength of $2.67 \mathrm{MPa}$.
\end{abstract}

Keywords : HDPE, concrete, aggregate

\begin{abstract}
Abstrak : HDPE atau High Density Polyethylene merupakan salah satu bahan material plastik yang banyak digunakan untuk pembuatan kemasan berbahan plastik. Beton adalah sebuah bahan bangunan komposit yang terbuat dari kombinasi agregat dan pengikat semen. Berat jenis agregat kondisi SSD diperoleh sebesar 1,15 (syarat agregat ringan antara 1 sampai 1,8) dan memiliki tingkat penyerapan terhadap air (absorpsi) sebesar 3,945\% (syarat maks. 3,5\%), berat isi kering $1378 \mathrm{~kg} / \mathrm{m}^{3}$ (syarat maks. $1800 \mathrm{~kg} / \mathrm{m}^{3}$ ) serta ketahanan aus (abrasi) agregat buatan sebesar 29,64\% (syarat agregat dipakai untuk beton maks. 40\%). HDPE adalah jenis plastik yang berwarna putih susu/putih bersih. Digunakan untuk kantong tissue, botol detergent, minyak, plastik anti panas, pipa plastik, shopping bag dan kantong plastik yang biasa untuk sayur makanan yang berkuah. Kekuatan tekan beton terbesar diperoleh pada pemberian suhu sampai $90^{\circ} \mathrm{C}$ yakni sebesar 13,16 MPa. Bila beton dicampur dengan 20\% limbah HDPE menghasilkan kuat tekan beton sebesar 11,08 MPa. Namun, beton yang dicampur dengan limbah HDPE yang dibuat simpul menghasilkan kuat tekan beton sebesar 2,67 MPa.
\end{abstract}

Kata Kunci : HDPE, beton, agregat

\section{PENDAHULUAN \\ Latar Belakang}

HDPE atau High Density

Polyethylene merupakan salah satu bahan material plastik yang banyak digunakan untuk pembuatan kemasan berbahan plastik. Dikutip dari laman internasional kompas bahwa berdasarkan data dari scieneMag, jumlah produksi sampah plastik global sejak 1950 hingga 2015 cenderung selalu menunjukkan peningkatan. Pada tahun 1950, produksi sampah dunia ada di angka 2 juta ton per tahun. Kemudian pada 2015 produksi sampah sudah ada di angka 381 juta ton. Maka dari itu perlu adanya penanganan untuk mengurangi limbah tersebut salah satunya adalah dengan mengaplikasikan limbah plastik menjadi salah satu material beton.

Beton adalah sebuah bahan bangunan komposit yang terbuat dari kombinasi agregat dan pengikat semen. Beton memiliki banyak material yang diambil dari alam, salah satunya adalah agregat. Dalam jurnal ini penulis tertarik untuk 
membahas penggunaan material limbah HDPE sebagai pengganti agregat beton. Penggunaan material pengganti agregat beton seperti limbah HDPE yang bersifat cukup ringan sehingga menjadi solusi alternatif dalam pengelolaan limbah HDPE itu sendiri dan mengurangi berat sendiri pada struktur bangunan.

\section{Formulasi Masalah}

Berdasarkan latar belakang yang telah dijelaskan diatas, rumusan masalah yang dapat penulis ambil, yaitu:

1) Berapakah nilai kuat tekan beton dengan agregat berbahan limbah HDPE?

2) Bagaimanakah karakteristik material agregat berbahan HDPE?

\section{Tujuan}

Tujuan dari penelitian ini adalah untuk mengetahui kuat tekan pada beton yang telah dicampur dengan agregat berbahan HDPE, selain itu jurnal ini diharapkan agar dapat mengurangi limbah HDPE yang saat ini semakin memprihatinkan terutama di Indonesia. Tujuan dari jurnal ini antara lain:

1) Mengetahui nilai kuat tekan pada beton yang dicampur dengan agregat berbahan HDPE;

2) Mengetahui karakteristik agregat berbahan HDPE.

\section{Sistematika Penulisan}

Jurnal ini dibagi menjadi enam bab dengan sistematika penulisan sebagai berikut:

\section{PENDAHULUAN}

Berisi mengenai latar belakang, formulasi masalah, tujuan dan sistematika penulisan terkait dengan jurnal penelitian.

\section{METODOLOGI}

Berisi mengenai uraian pelaksanaan penelitian mulai dari tahap persiapan, pegumpulan data hingga metode yang digunakan untuk menyusun Jurnal penelitian.

\section{PEMBAHASAN}

Berisi tentang proses analisis data seperti analisis mengenai kuat tekan beton yang telah dicampur dengan agregat berbahan HDPE, serta analisis perbandingan kualitas antara beton dengan agregat berbahan HDPE dan beton dengan agregat biasa.

\section{KESIMPULAN}

Berisi kesimpulan berdasarkan hasil penelitian yang diperoleh sebagai masukan pembaca maupun penelitian selanjutnya.

\section{METODOLOGI}

Metodologi merupakan sebuah cara untuk mengetahui hasil dari sebuah permasalahan yang spesifik, dimana permasalahan tersebut disebut juga dengan permasalahan penelitian. Dalam pengumpulan data pada jurnal ini menggunakan metode kajian literatur yang didukung referensi dari berbagai jurnal penelitian. Kajian literatur adalah sebuah uraian tentang literatur yang relevan dengan topik tertentu.

Penulis mengambil 3 jurnal yang berkaitan dengan topik. Berikut judul penelitian yang penulis ambil:

1. B. Soebanono, dkk. "Prilaku Kuat Tekan dan Kuat Tarik Beton Campuran Limbah Plastik HDPE". 2013

2. Mohtarom Riyadi, dkk. "Pemanfaat Limbah Plastik Simpul Sebagai Pengganti Agregat Kasar Pada Beton". 2015.

3. Erwin Rommel. "Pembuatan Beton Ringan Dari Agregat Buatan Berbahan Plastik". 2013.

Data yang diambil terdiri dari Kuat Tekan Beton dan Karakteristik Agregat Plastik.

\section{PEMBAHASAN}

\section{Karakteristik Agregat Plastik}

Agregat ringan buatan dari limbah plastik HDPE memiliki permukaan yang lebih licin dan mengkilap (polished), hal tersebut dapat mengurangi kualitas ikatan antar agregat dan kekuatan beton secara keseluruhan, tetapi agregat buatan tersebut memiliki bentuk yang acak dan bersudut. Berat jenis agregat kondisi SSD diperoleh sebesar 1,15 (syarat agregat ringan antara 1 sampai 1,8) dan memiliki 
tingkat penyerapan terhadap air (absorsi) sebesar 3,945\% (syarat maks. 3,5\%), berat isi kering $1378 \mathrm{~kg} / \mathrm{m}^{3}$ (syarat maks. 1800 $\mathrm{kg} / \mathrm{m}^{3}$ ) serta ketahanan aus (abrasi) agregat buatan sebesar 29,64\% (syarat agregat dipakai untuk beton maks. 40\%). Agregat plastik memiliki gradasi yang kurang baik karena terjadi gap-gradation akibat perolehan ukuran dan bentuk agregat yang dilakukan secara manual (melalui penumbukan dengan palu). Hal tersebut juga akan berpotensi terjadinya porous pada beton menjadi lebih besar, (Erwin Rommel, 2013).

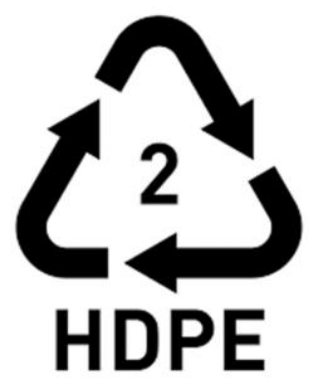

Gambar 1. Kode plastik HDPE (Sumber : en.wikipedia.org)

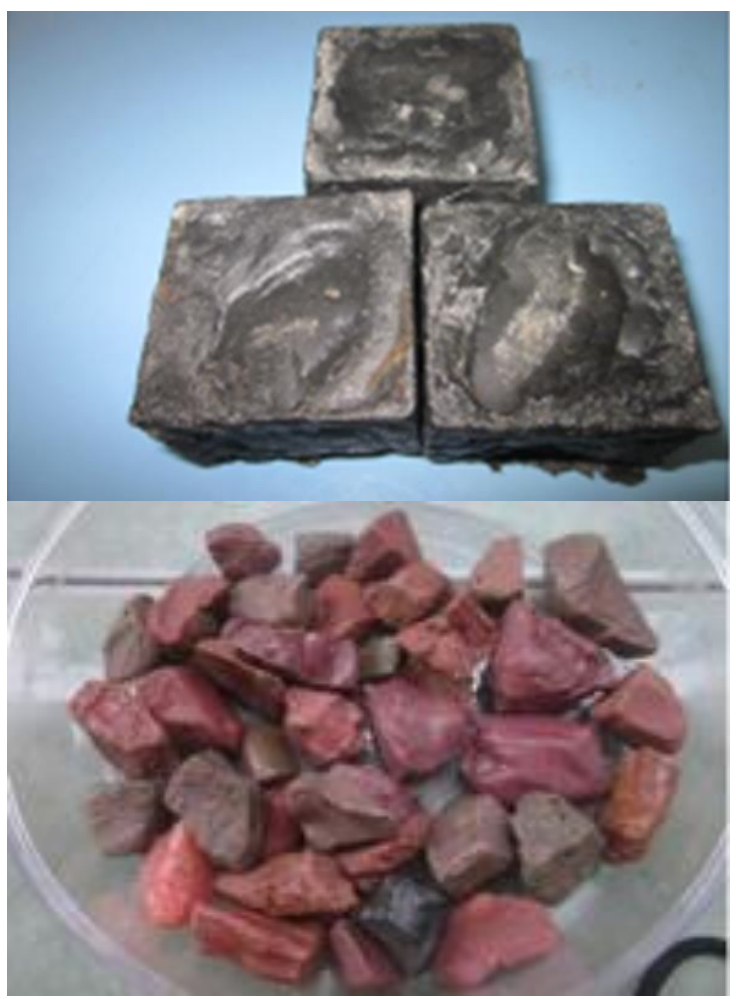

Gambar 2. Agregat ringan buatan dari limbah plastol HDPE Sumber : Erwin Rommel, 2013
Polythylene dihasilkan dari proses polimerisasi molekul-molekul gas ethylene secara bersama-sama membentuk rangkaian panjang molekul sampai menjadi bentuk plastik (polimer). Permukaan dari limbah plastik HDPE licin dan halus, sehingga ikatan antar partikel penyusun beton kurang kuat dibanding dengan beton normal. Selain itu dari segi kekuatan limbah plastik HDPE lebih lunak dibanding dengan batu pecah, $(B$. Soebandono, et al, 2013).

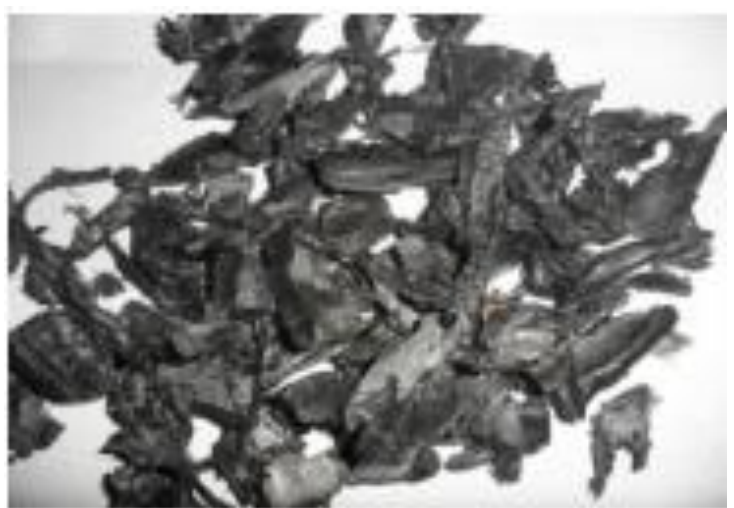

Gambar 3. Limbah plastik HDPE ukuran lolos saringan $19 \mathrm{~mm}$ dan tertahan saringan $4,75 \mathrm{~mm}$

Sumber : B. Soebandono, et al. 2013.

HDPE adalah jenis plastik yang berwarna putih susu/putih bersih. Digunakan untuk kantong tissue, botol detergent, minyak, plastik anti panas, pipa plastik, shopping bag dan kantong plastik yang biasa untuk sayur makanan yang berkuah, (Mohtarom Riyadi, 2015).

\section{Metode Pengujian Agregat Plastik HDPE}

Berat jenis agregat kondisi kering permukaan (SSD) yang hampri mendekati berat jenis air $(\mathrm{BJ}$ air $=1,0)$ memerlukan perlakuan tersendiri saat pencampuran beton dilakukan akibat adanya agregat plastik mengambang kepermukaan beton ketika proses pengadukan maupun pengecoran yang sangat mungkin terjadi. Untuk mendapatkan workability beton yang baik maka penggunaan jumlah air yang tepat dapat dilakukan dengan metode tral-error terlebih dahulu. Proses 
pencampuran dilakukan dengan mencampur terlebih dahulu pasir dan semen sebelum memasukkan air kedalam adukan beton. Agregat plastik ditambahkan secara perlahan-lahan sambil proses pengadukan dilakukan. Hal ini akan mengurangi mengambangnya agregat plastik tersebut, disamping itu perlu diperhatikan adalah kekhawatiran akan terjadinya segregasi pada beton dimana pada bagian permukaan akan terkumpul agregat plastik tersebut. Hal ini dapat diatasi dengan pemadatan beton dilakukan dengan metode penggetaran diatas meja getar saat pembuatan silinder beton uji, sedangkan untuk dilapangan pemedatan dilakukan dengan memukul bagian samping bekisting secara perlahan-lahan. Pengujian tingkat keausan agregat pada mesin Los Angeles yang diputar sebanyak 500 putaran dengan kecepatan $30 \mathrm{rpm}$ menghasilkan tingkat abrasi yang cukup baik dimana rata-rata kandungan agregat yang lolos pada saringan No, 12 sebanyak $29,64 \%$. Untuk pengujian kuat tekan hancur agregat dilakukan dengan membuat agregat plastik berbentuk mortar $(5 \times 5 \times 5)$ $\mathrm{cm}$, dan diuji tekan pada mesin, diperoleh kuat tekan hancur agregat rata-rata sebesar $98 \mathrm{~kg} / \mathrm{cm}^{2}$, (Erwin Rommel, 2013).

Plastik HDPE digunakan sebagai pengganti sebagian agregat kasar untuk mengetahui prilaku nilai kuat tekan dan kuat raik belah beton. Limbah plastik HDPE yang dipakai adalah HDPE dengan ukuran lolos saringan $19 \mathrm{~mm}$ dan tertahan saringan 4,75 $\mathrm{mm}$ sebagai pengganti agregat kasar, (B. Soebandono, 2013).

Alat yang digunakan pada pengujian adalah mesin Loas Angeles untuk menguji tingkat keausan agregat kasar. Pada pemeriksaan (limbah plastik HDPE) tidak dilakukan pemeriksaan secara khusus terhadap agregat limbah plastik HDPE. Pemeriksaan yang dilakukan hanya pemeriksaan ukuran agregat. Pengadukan menggunakan mesin molen, kerikil dan pasir dicampur terlebih dahulu sampai bercampur. Selanjutnya semen dimasukkan ke dalam molen, setelah tercampur rata, air dimasukkan setengah takaran dahulu kemudian air sisa dimasukkan. Untuk limbah HDPE, agregat limbah dimasukkan setelah campuran beton tercampur rata dan dimasukkan sedikit demi sedikit sampai tercampur rata, (B. Soebandono, et al, 2013).

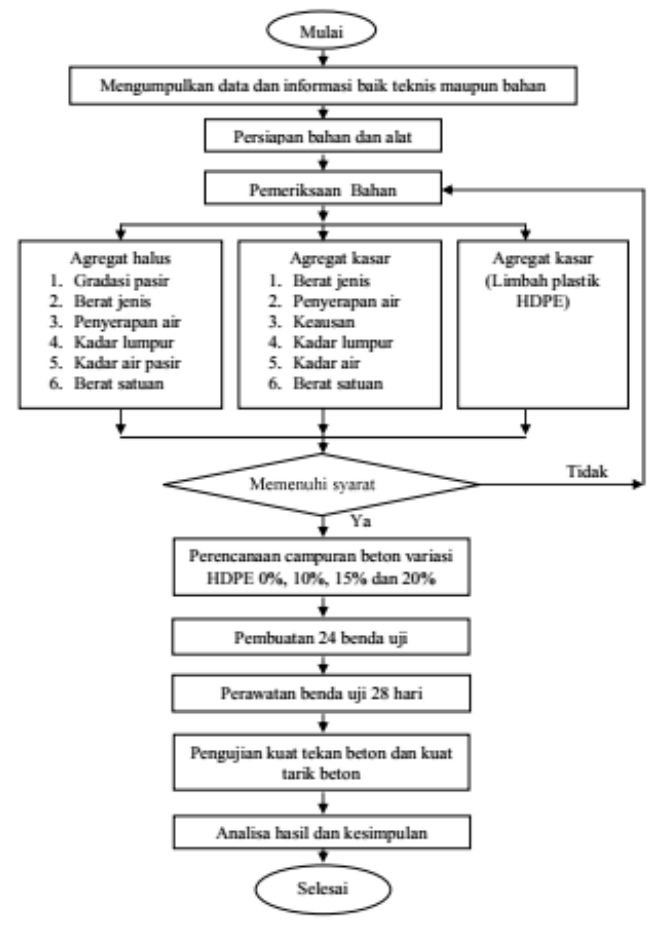

Gambar 4. Bagan alir penelitian

Sumber : S. Soebandono, et al. 2013

Pada pengujian kantong plastik HDPE dibuat simpul agar keras dan memiliki gradasi yang memenuhi persyaratan agregat kasar dalam pembuatan beton. Pada pengujian ini bertujuan untuk mendapatkan karakteristik agregat kasar buatan dari limbah kantong plastik HDPE yang dibuat simpul serta sifat fisis dan mekanis beton dengan limbah kantong plastik jenis HDPE yang dibuat simpul sebagai subtitusi agregat kasar. Terdapat variasi terhadap agregat kasar tersebut yaitu dengan mensubtitusikan agregat kasar buatan dari limbah kantong plastik jenis HDPE yang dibuat simpul dengan kadar 0\%, 50\% dan $100 \%$ terhadap batu pecah. Pada hasil pengujian BJ agregat kasar HDPE yang dibuat simpul, didapat sebesar 0,57. 
Agregat tersebut dikategorikan sebagai agregat ringan berdasarkan berat jenisnya, karena memiliki BJ < 2,0 menurut SK SNI S-04-1989-F. Hasil pengujian berat isi pada agregat kasar HDPE yang dibuat simpul didapat berat isi lepas sebesar 0,24 $\mathrm{gr} / \mathrm{cm}^{3}$ dabn berat isi padat sebesar 0,3 $\mathrm{gr} / \mathrm{cm}^{3}$. Berdasarkan gambar 5. Agregat kasar buatan HDPE memenuhi persyaratan gradasi untuk agregat kasar menurut standar ASTM C-33-78 dengan ukuran nominal $19 \mathrm{~mm}$, (Mohtarom Riyadi, dkk, 2015).

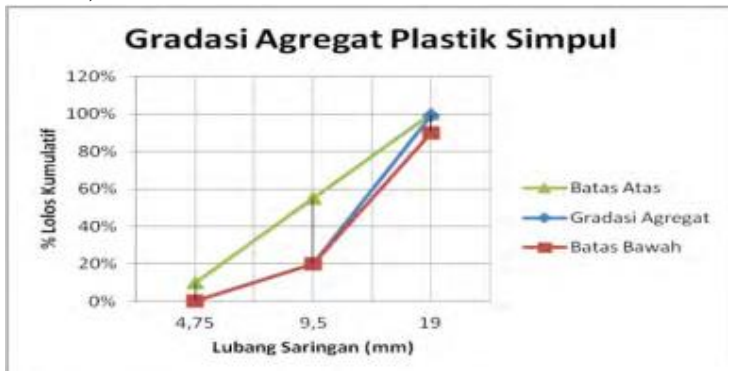

Gambar 5. Grafik batas gradasi agregat kasar buatan dari lmbah kantong plastik jenis HDPE yang dibuat simpul Sumber : Mohtarom Riyadi, dkk. 2015.

\section{Kuat Tekan Beton}

Pengujian kuat tekan beton dilaksanakan setelah benda uji berumur 28 hari. Pengujian kuat tekan beton dilakukan untuk mmperoleh nilai kuat tekan beton dengan adanya perbedaan variasi suhu pemanasan beton. Agregat plastik yang dipakai sebesar 562,15 kg dan diberi perlakuan panas. Pemberian perlakuan panas dilakukan dengan cara memasukkan kedalam oven selama 24 jam pada suhu $90^{\circ}$ C. Kekuatan tekan beton terbesar diperoleh pada pemberian suhu sampai $90^{\circ}$ C yakni sebesar 13,16 $\mathrm{MPa}$ atau meningkat $20 \%$ dibandingkan dengan beton ringan yang tidak diberi perlakuan panas, (Erwin Rommel, 2013).

Pada pengujian, hasil uji kuat dimana beton dicampur dengan 20\% limbah HDPE menghasilkan kuat tekan beton sebesar 11,08 MPa, (B. Soebandono, et al. 2013).

Dari Gambar 6, semakin banyak campuran limbah HDPE, semakin menurun juga kekuatan tekan beton. Hal ini dikarenakan permukaan dari limbah plastik HDPE licin dan halus, sehingga ikatan antara partikel penyusun beton kurang kuat dibanding dengan beton normal. Selain itu dari segi kekuatan limbah plastik HDPE lebih lunak dibanding dengan batu pecah, (B. Soebandono, et al, 2013).

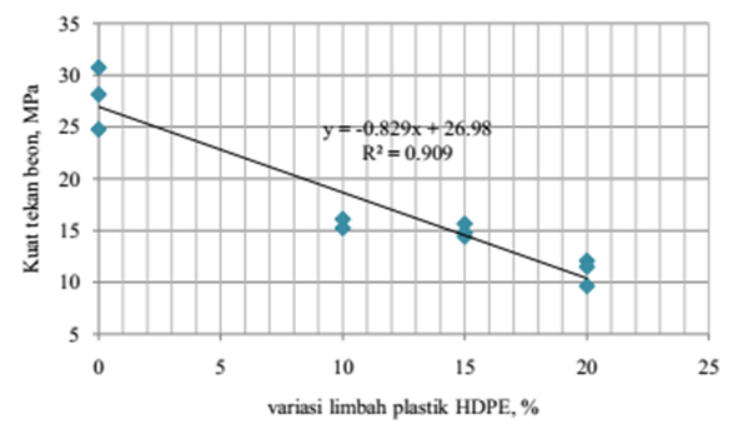

Gambar 6. Hubungan antara nilai kuat tekan beton dengan variasi persentase limbah plastik

Sumber : B. Soebandono, et al. 2013.

Kuat tekan adalah besarnya beban per satuan luas. Nilai kuat tekan didapat melalui pengujian standar menggunakan mesin uji. Dari hasil pengujian kuat tekan beton pada gambar 7 dapat dilihat bahwa semakin banyak persentase limbah kantong plastik HDPE yang dibuat simpul digunakan untuk menggantikan kerikil sebagai agregat kasar, maka kuat tekan beton semakin berkurang, (Mohtarom Riyadi, dkk. 2015).

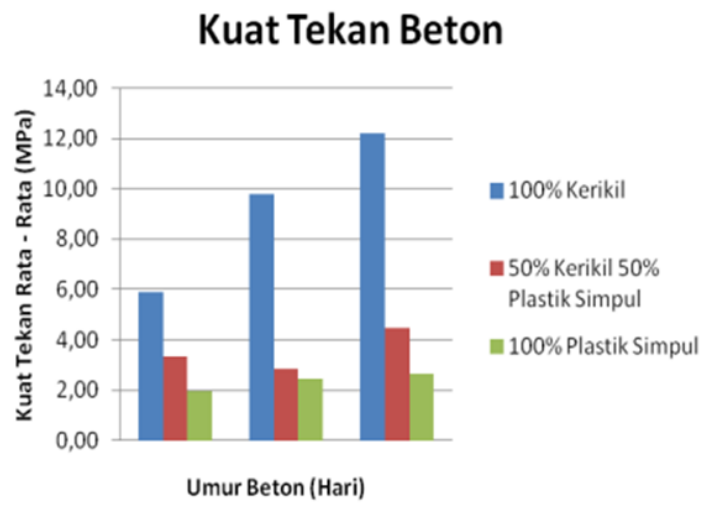

Gambar 7. Diagram hubungan antara kuat tekan beton dengan persentase subtitusi 
agregat kasar yang digunakan

Sumber : Mohtarom Riyadi, dkk. 2015.

Dari hasil pengujian kuat tekan beton dari ketiga penelitian diatas, dapat dirangkum dalam Tabel 1. Kualitas mutu beton dengan menggunakan aggregat berbahan HDPE kurang dibandingkan beton dengan aggregat konvensional. Sehingga, penggunaan beton ringan dengan penggunaan aggregat berbahan HDPE hanya digunakan untuk elemen struktur ringan sperti panel pracetak, kusen beton, clading beton dan ornamen, (Erwin Rommel, 2013).

Tabel 1. Akumulasi kuat tekan beton dari 3 jurnal berbeda

\begin{tabular}{ccc}
\hline $\begin{array}{c}\text { Jurnal } \\
\text { Erwin }\end{array}$ & $\begin{array}{c}\text { Jurnal } \\
\text { Bommel, } \\
\text { et al, 2013 }\end{array}$ & $\begin{array}{c}\text { Jurnal } \\
\text { Mohtarom }\end{array}$ \\
$\mathbf{2 0 1 3}$ & & $\begin{array}{c}\text { Riyadi, dkk, } \\
\mathbf{2 0 1 5}\end{array}$ \\
\hline $13,16 \mathrm{MPa}$ & $11,08 \mathrm{MPa}$ & $2,67 \mathrm{MPa}$ \\
\hline
\end{tabular}

\section{KESIMPULAN}

Dilihat dari hasil analisis diatas, maka dapat disimpulkan bahwa:

1. Agregat ringan buatan dari limbah plastik HDPE memiliki permukaan yang lebih licin dan mengkilap (polished), hal tersebut dapat mengurangi kualitas ikatan antar agregat dan kekuatan beton secara keseluruhan, tetapi agregat buatan tersebut memiliki bentuk yang acak dan bersudut.

2. Dari segi kekuatan limbah plastik HDPE lebih lunak dibanding dengan batu pecah.

3. Limbah HDPE biasa digunakan untuk kantong tissue, botol detergent, minyak, plastik anti panas, pipa plastik, shopping bag dan kantong plastik yang biasa untuk sayur makanan yang berkuah.

4. Hasil kuat tekan beton yang diberikan perlakuan panas sebesar $90^{\circ} \mathrm{C}$ menghasilkan kuat tekan sebesar 13,16 MPa.

5. Hasil kuat tekan beton yang dicampur dengan HDPE dengan proporsi 20\% menghasilkan kuat tekan beton sebesar 11,08 MPa.

6. Hasil kuat tekan beton yang dicampur dengan limbah HDPE yang dibuat simpul menghasilkan kuat tekan beton sebesar 2,67 MPa.

\section{DAFTAR PUSTAKA}

1. Ayu Azanella, L, Sampah Plastik Dunia dalam Angka, diambil dari https://internasional.kompas.com/read/ 2018/11/21/18465601/sampah-plastikdunia-dalam-angka, 2018.

2. Marzali A., Menulis Kajian Literatur, 2006.

3. Rommel, E., Pembuatan Beton Ringan dari Agregat Buatan Berbahan Plastik, Vol. 9, No. 1, 141, diambil dari http://ejournal.umm.ac.id/index.php/g amma/article/view/2417

4. Wikipedia bahasa Indonesia, Beton, diambil dari https://id.wikipedia.org/wiki/Beton

5. Wikipedia bahasa Indonesia, Polietilena berdensitas tinggi, diambil dari https://id.wikipedia.org/wiki/Polietilen a_berdensitas_tinggi. 
